\title{
MEASURES TO IMPROVE LIFE INSURANCE PROFITABILITY IN INDIA
}

\author{
Ramesh Kumar Satuluri \\ Research Scholar \\ Department of Management \\ GITAM University \\ Hyderabad, India \\ E-mail: ramesh.satuluri@exidelife.in \\ Raavi Radhika \\ Associate Professor \\ Department of Management \\ GITAM University \\ Hyderabad, India \\ E-mail: radhika.ramanchi@gitam.edu
}

\begin{abstract}
With $\sim 32$ crore policies in-force and over $\sim 11000$ branches across locations, Life Insurance Industry in India is the 10th largest across the globe in terms of premium contribution. India's share in Global Life Insurance Market was 2.73\% during 2019. The life insurance industry is also one of the largest employers with both direct and indirect employment. Life Insurance penetration in India is at $2.82 \%$ and density at 58 USD, which is way below the global statistics. This gives immense opportunity for global players to venture into the Indian insurance market. With a proposal for an FDI hike to 74\%, we are expecting many big players to enter the Indian market. However, the attractiveness of the industry not depends solely on the market opportunity but also on the bottom line, which is profitability. Indian Insurance Industry is one of the highly regulated markets across the globe and perceived to be the lowest profit-making insurance market. Hence, the need for the study to improve the profitability of life insurance companies in India through structural and policy measures.
\end{abstract}

Keywords: Life Insurance, Profitability, Profit, Insurance Industry, Insurance.

JEL Classification Codes: G22, I13, O16, A10, E22, G10.

\section{INTRODUCTION}

Indian Insurance Industry remains the most attractive destination for foreign players with penetration as low as $3.76 \%$ as on 2019. Opening the sector for private players can be traced back to the passage of IRDAI Act 1999, which allowed foreign players to tie up with domestic insurers in setting up their operations. As of now, Life Insurance Industry has 24 players, which include the Government owned Life Insurance Corporation. In spite of LIC being operational for 44 years i.e. from 1956 to 2000, our penetration remains one of the lowest across the globe. Total collected premium for Life Insurance Industry grew from 34898 crores (FY 2000-2001) to 572910 crores (FY 2019-20) at a CAGR of 
$15 \%$.With the advent of private insurance companies, industry could witness greater awareness being created for life insurance products. Product innovation is the other area, which had picked up after competition between insurance players. Insurance industry is capital-intensive industry. Foreign companies in addition to technological innovation have also brought-in capital, which is invested in setting up new branches and building distribution. In order to encourage digital way of selling, support innovation in product designing, IRDAI formed a sandbox committee wherein approvals were accorded on use and file concept.

Today Life Insurance industry is next to banks in terms of pooling savings across the country. Financial institutions play a vital role in funding fiscal deficit of Government of India. GOI primarily depends on savings and remittances to fund the ongoing projects and handle any balance of payment crisis. Gross savings rate in India by March'19 remained at 29.7\%. India as a country always remained a net saver and financial institutions remain at the forefront in funding country's infrastructure plans. As on 30 September'20, investments in infrastructure exceeded 4.27 lakh crores from the collected premium of life insurance industry. In order to encourage more Foreign Direct Investments in insurance sector, govt. passed Insurance ordinance in 2015 to increase FDI from 26\% to $49 \%$ and $100 \%$ FDI in insurance intermediaries. This prompted many existing foreign partners to increase their stake in respective joint ventures. In the recent budget, GOI further proposed a hike of FDI in insurance to $74 \%$.Also for most of the insurance companies who have not listed on bourses, this has come at an apt time to unlock their firm's value by diluting their stake to existing or new partners. Life insurance industry also is one of the largest employers with 2.93 lakhs direct employment and another 23.9 lakhs into indirect employment as on 30 September'20.

\section{LITERATURE REVIEW}

Bidabad (2019) researched on design of new insurance products in Rastin Profit and Loss sharing (PLS) Banking. These products can be used in both banking operations as well as conventional business and financial arrangements. Researcher highlights the importance of designing right product, which meets customer needs, and at the same time, these products influence the profitability since these products are offered by insurance company's basis their actuarial calculation once the design work is completed by the bank.

Choudhury, Singh, Kajol and Rai (2020) researched on the theme "Empathy of the bancassurance channel: an empirical study". Researcher in this article highlighted the empathy exhibited by banc assurance channel on customers. Finally researcher concludes that customer opine that banc assurance channel have a high level of empathy towards customers. Hence, Insurance companies can utilize banc assurance as the distribution model to sell their products and services thus increase productivity and higher profitability.

Tanwar, Seth, Vaish and Rao (2020) conducted study on "Revisiting the Efficiency of Indian Banking Sector: An Analysis of Comparative Models through Data Envelopment Analysis". Researcher examined the efficiency of overall banking industry using Data Envelopment Analysis (DEA). Researcher ranked banks basis the efficiency parameters. The results showed that most of the Indian banks fall on the efficient side or are near to full efficiency. Banker's efficiency is directly proportionate to the profitability of banks.

Diepiriye (2018) conducted study on "International Financial Reporting Standards and Value Relevance of Accounting Information: A Mult-Institutional Perspectives from Nigeria". The study was primarily to understand the correlation between IFRS and the firms operating in Nigeria including insurance companies. The study concludes that there is a significant relationship between IFRS and value relevant of accounting information of firms in Nigeria. As of now Indian Insurance Industry, 
follows Non-IFRS accounting and IFRS-17 implementation is expected to kick off from1st April 2023. Implementation of IFRS-17 will have a direct and positive bearing on profitability of life insurance companies in India.

Gulati, Nancy (2015) researched on "Operational efficiency of life insurance companies in India". Researchers attempted to present the operational efficiency and revenue efficiency of the selected group. Data considered for this study was between 2001 and 2012 and the sample size of 12 insurance companies considered for the study. For measuring operational efficiency, researches used CARAMEL Method. Basis the research, they concluded that in order to bring-in efficiency in life insurance companies, researchers suggested that companies will have to go for more equity capital, windup unprofitable branches, diversify investment portfolio and adopt cost effective distribution system. Researchers also made few suggestions to IRDAI viz. enhancing FDI to 49\%, new regulations in areas of product pricing and risk evaluation to place them on a better situation in terms of solvency ratios.

Hamsini and Rashmi (2019) researched on "A Study on Effectiveness of the Crop Insurance in Karnataka -With Special Reference Chikmagalur District”. In this study, the researcher highlighted that buying crop insurance was dependent on factors like come, availability of loan on crop, financial security and awareness about the products. Finally, the researcher concluded that crop insurance indeed is helping farmers to safeguard themselves against unforeseen events.

\section{PROFITABILITY}

During the financial year 2018-19, life insurance industry reported net profit of 8435.81 crore as against 8511.99 crore in 2017-18.Out of the twenty four life insurers in operations during 2018-19, twenty companies reported profits. LIC reported net profit of 2688.50 crore i.e. an increase of 9.8 per cent over 2446.41 crore in 2017-18. On the other hand, private insurers reported a net profit of 5741.31 crores a decrease in profit from the previous year 6064.32 crores.

However all these companies reported only accounting profit and the accumulated losses are mounting which is a major cause of concern.

\section{SUGGESTIONS}

In order to enhance profitability of life insurance companies in India, following suggestions are recommended and the same can be categorized basis the stakeholder.

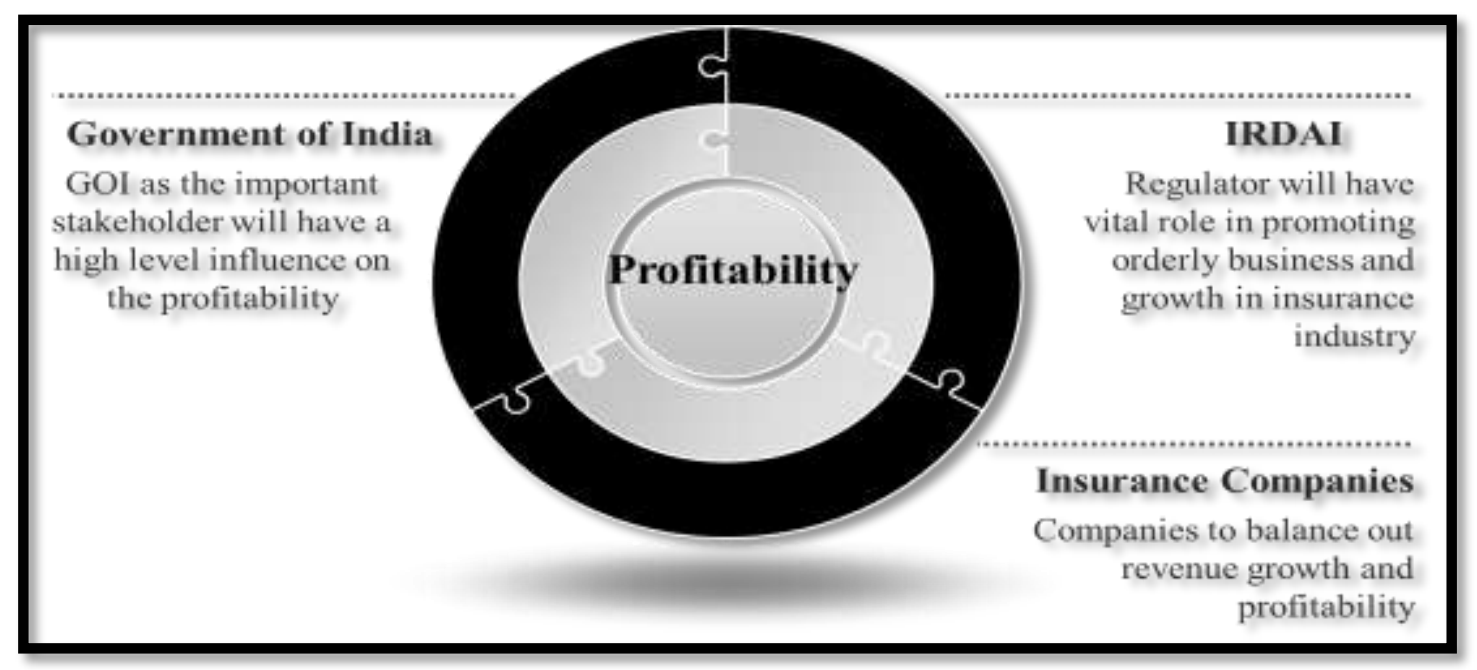




\section{Government of India (GOI)}

\section{Treatment of Acquisition Cost and its Impact through Ind AS}

Since Indian life insurance companies do not follow IFRS accounting, which allows for deferring the acquisition cost, every new business written without sufficient solvency is a business strain. IRDAI should standardize the accounting practices and align them with global practices wherein the initial acquisition cost is deferred so that companies would make profit from the accounting perspective. Non-IFRS accounting practice would discourage insurance companies to infuse further capital as everything is reflected in the accounting year. As per the earlier draft exposure from IRDAI, life insurance companies were supposed to implement Ind AS (Indian Accounting Standards) effective 1 April 2020. Now it is deferred further since IFRS-17 was going through certain changes and the same will be notified by mid-2020. Hence, IRDAI wanted to hold the implementation until they get clarity on IFRS so that necessary changes can be made in Ind AS. It was also deferred considering the cost involved and the asset and liability mismatch in the accounting process. This is very crucial for insurance companies to register profits as Non-IFRS method of reporting entire cost in the same financial year is discouraging insurance companies from expanding their branch network and operations.

\section{Foreign Direct Investment- A Key Determinant for Insurance Penetration}

FDI in insurance remained at $49 \%$ for some years. However, the recent budget proposed a hike to $74 \%$, which is a welcome. FDI in insurance intermediaries is at $100 \%$. With $49 \%$ in place for some years, there was a greater amount of euphoria and excitement in the industry with the expectations that foreign partners will enhance their stake. To an extent, it has happened in few cases but Indian partners were consciously offloading their stakes only to book profits than investing the stake money in building distribution. Investing in distribution had hardly taken place and witnessed many foreign partners exiting from insurance market to name a few ING Group, ANP, AIG, Newyork etc. This has come as a jolt to the efforts of GOI in attracting foreign participation. Insurance industry in India is always perceived as the least profit making insurance industry across the globe due to stringent regulations, ultra-conservatism and the accounting practices. India had 240+ insurance companies before 1956 and eventually they were merged with the LIC act. When GOI started privatization in life insurance industry, they were also expecting similar kind of participation from various companies. However, eventually ended up having only 24 companies and do not see any other companies keenly interested in setting up their operations. This issue needs to be drilled down further to understand as to why companies are hesitant to start operations in India. An advance economy like USA has 800+ life insurance companies and Taiwan has close to $\sim 20 \%$ insurance penetration. India is no way closure to these figures.

\section{IRDAI (Regulator)}

Uniform Commission Structure: Regulator should ponder upon introducing uniform commission structure. This will to an extent reduce mis-selling and average out the initial expense incurred at the time of sourcing the policy. It also should help the agent to focus more on renewals since the spread of commission is even.

Product Portability: Regulator should look at allowing portability of standard products, which will encourage companies to maintain higher standards of precision on customer retention. This should also 
reduce mis-selling since the end objective is to retain customer for a long term. Product portability can go together with implementation of IFRS, which allows companies to amortize the cost of acquisition and with minimum lock in period to ensure that the expense spread is recovered.

Mandatory listing provision: Recent amendment has removed the mandatory listing requirement for insurance companies. We need to repeal the condition as mandatory listing requirement will keep companies on guard and alert to meet the market regulator requirements. This will continue to bring in efficiency and cost containment.

Higher Equity Exposure: IRDAI should allow change in investment guidelines to increase equity exposure from existing $15 \%$ to $25 \%$. This should allow companies to better their investment return without taking huge risk. Since most of the contracts are long term in nature, higher exposure to equity will not be a risky proposition and the market volatility would be averaged over a period. Higher equity exposure is also required due to prevailing interest rates. Interest rates are expected to dwindle further, which may affect the return assumptions made at the time of product design.

Need for Co-Insurance than Reinsurance: IRDAI needs to encourage through regulations for companies to accept more risk than ceding to reinsurance companies. This way companies will fulfil the basic responsibility of accepting risk. If at all a need arises, companies should be allowed to go ahead for co-insurance among themselves than reinsurance. This way premium is being distributed among themselves and companies with higher solvency margins can accept greater risk than idling the solvency margin.

Amendment of Insurance Act for Surplus Distribution: Presently industry has a portfolio of products with an equal contribution from both PAR and Non-PAR products. As per the act, surplus distribution on PAR products is 90:10 which means 90\% of surplus after reserving needs to be distributed to policyholders and $10 \%$ goes to share holder account. Instead of $90 \%$, the proposal is distributing $85 \%$ to policyholders and diverting another $5 \%$ to shareholders account thus reducing the break-even phase for LI companies.

\section{Insurance Companies}

Develop Digital Distribution Strategy

Digital signifies an incessant form of disruption to present, new business models, products, services or experiences enabled by data and technology. Efficiently leveraging on digital revolution can let life insurance companies lessen customer service costs while augmenting both customer satisfaction and retention. Currently Insurance Companies are sourcing only term plans through online sales. Since it is only beginning, industry cannot compare the quantum of premium sourced through online, since term plans ticket size will be very low. Biggest advantage here would be reduced cost of acquisition, which can be passed on to customers, which in turn will enhance top line and bottom line. Insurance companies have a positive aspect in these pandemic days. With social distancing as a norm, companies are witnessing a renewed vigour on online transactions. Digital transformation in life insurance sector is initiated both the at the payment space and on distribution front. 


\section{Implement Data Analytics and Technological Innovation}

Life insurance industry always remained highly competitive. In addition, amidst this uncertainty and inflated costs, the only tactic to grow both top line and bottom line is by acquiring quality customers and retaining them. By identifying quality customers and retaining most of them requires a focused approach and this is possible only through analytics viz., understanding customer priorities, behaviour and buying patterns. Analytics can be defined as studying the historical data to identify a particular trend and predicting the future. Main aim of analytics is to study the behaviour of the customer and manufacture a product basis his/her need.

\section{Identify Areas for Expense Reduction/Efficiency Build Up}

According to analysis, a life insurer can enhance its return on equity by 2.5 percent through cost cutting and a further 0.6 percent by optimizing commission structures and processes. It is simply that cost reduction must be seen at the strategic level. Companies of course, typically have a number of costreduction programs underway at any point of time. Nevertheless, these are very limited in scope. What needs to be discussed here is perpetual cost containment and that denotes rationalizing and restructuring the operational model.

\section{Embedded Value and Value New Business}

Embedded value is the present value of future profits plus Adjusted Net worth of the company. It is one way of valuing the organization. Embedded value will consider all in-force policies and the net worth of the organization for a particular period. In-force policies keeps on going up on a regular basis as well as your net worth thus enhancing your embedded value. Embedded value will not factor new business or forthcoming business and goodwill of the organization. It will consider only inforce policies and net worth. Hence, once the embedded value is calculated generally organizations will have two or three multiple on embedded value as the valuation. Higher multiple will factor future business and the goodwill of the organization. Companies need to ensure that the inforce policy base keeps on going up without causations.

On the other hand, Value New Business is the present value of profit for the business written in a particular period. VNB is at product level and EV is at organizational level. VNB is based on assumptions made pertaining to persistency, mortality and expenses and the final return post that. In simple terms if a contract is written for Rs.100 and company is going to make Rs.20 at the end of the contract then VNB margin is stated as $20 \%$. VNB margin generally is higher for Non-participating plans like protection and ULIP plans. This is so because there is no surplus distribution for non-par plans as the surplus money is straight away booked as profit and transferred to shareholders account. Companies will have to focus more on inforce policy base along with net worth and start greater mix of products with higher VNB margins.

Once this is assured then industry can witness quality agents getting into profession leading to higher productivity and retention thus having a positive impact on entire profitability.

\section{CONCLUSION}

Initially Indian Life Insurance Companies were completely focused on business expansion and driving revenue targets, which is top line. However, with the regulatory interventions and expectations from shareholders, insurance companies started emphasizing on bottom line. Also with the latest regulation on expense management from IRDAI, focus completely shifted to profitability. Vintage companies with huge renewal base are surviving because of collectibles. Challenge lies for new companies, which do not have renewal base but also need to write new business premium. Industry is also not seeing much 
investment in distribution from insurance companies in India. With the advent of FDI, industry expected huge pump in of capital and some amount getting into distribution. However, companies have not seen much progress in this case. Companies with banc assurance tie up continue to generate good revenue with low cost. However, the fact remains that industry does not have many insurance companies, which have banc assurance tie up. IRDAI proposed open architecture wherein banks will have tie up with multiple insurance companies. In addition, as of now it is only given as an option for insurance companies to decide whether to have tied structure or follow open architecture. All insurance companies promoted by banks very well oppose this model. Hence, there is no much progress made on this open architecture. LIC is the only exception, which has one of the lowest opex to total premium ratio in spite of it completely depending on agency model.

\section{SCOPE FOR FURTHER RESEARCH}

Industry does not have much research happening on profitability of life insurance companies at advance level. Currently many researches restricted their analysis only to ratios or to an extent of applying few statistical tools with the available data. In addition, they do not have the entire data available on public disclosures viz. surrender profits made by companies, mortality experience of individual companies, underwriting profits made by insurance companies. Earlier researchers also choose a particular period to carry on their analysis on profitability, which may not give clear picture on profit. This is due to changing regulations on products and expense at regular intervals. Companies do not have any research on life insurance profitability since 2000 to till date and this is a gap, which was identified in this research. Organizations like IRDAI and IIB (Insurance Information bureau) should give enough data point to researchers to carry on advance research on profitability aspects. There is no much research happening on embedded value. While embedded value may not be directly linked to profitability but the fact remains companies make profit primarily when they off load the stake. In addition, with EV valuation wherein companies are expected to offload by 3-4 times of EV value it is pertinent to have thorough understanding on the way EV value is arrived at. Any research, which is done at a particular period, is bound to be fragmentary and incomplete due to changing regulations. Scope for further research also will be enhanced once majority of life insurance companies is listed. Once companies are listed then the information on profitability factors will become available to researchers which otherwise remain concealed and unavailable.

\section{REFERENCES}

Bidabad, B. (2019). Insurance Products in Rastin Profit and Loss Sharing Banking. Indian Journal of Finance and Banking, 3(1), 40-54. https://doi.org/10.46281/ijfb.v3i1.344

Choudhury, M., Singh, R., Kajol, K., \& Rai, S. K. (2020). Empathy of the Bancassurance Channel: An Empirical Study. Indian Journal of Finance and Banking, 4(4), 30-47. https://doi.org/10.46281/ijfb.v4i4.909

Diepiriye, D. (2018). International Financial Reporting Standards and Value Relevance of Accounting Information: A Mult-Institutional Perspectives from Nigeria Quoted Firms. International Journal of Accounting \& Finance Review, 2(2), 1-14. https://doi.org/10.46281/ijafr.v2i2.25

Gulati, N. C., \& Jain, C. M. (2011). Comparative analysis of the performance of all the players of the Indian life insurance industry. VSRD International Journal of Business and Management Research, 1(8), 561-569. 
Hamsini, P. H., \& Rashmi, R. (2019). A Study on Effectiveness of the Crop Insurance in Karnataka With Special Reference Chikmagalur District. Indian Journal of Finance and Banking, 3(2), 10-13. https://doi.org/10.46281/ijfb.v3i2.393

Tanwar, J., Seth, H., Vaish, A. K., \& Rao, N. V. M. (2020). Revisiting the Efficiency of Indian Banking Sector: An Analysis of Comparative Models Through Data Envelopment Analysis. Indian Journal of Finance and Banking, 4(1), 92-108. https://doi.org/10.46281/ijfb.v4i1.585

\section{Copyrights}

Copyright for this article is retained by the author(s), with first publication rights granted to the journal. This is an open-access article distributed under the terms and conditions of the Creative Commons Attribution license (http://creativecommons.org/licenses/by/4.0/) 